\title{
ANALISIS RESPON GERAK BARGE SEBAGAI TAMBAK GARAM LEPAS PANTAI DI PERAIRAN SELAT MADURA
}

\section{Analysis of Motion Responses of Barge as a Offshore Salt Pond in Madura Straits}

\author{
Arief Syarifuddin $^{1,}$, Tristiandinda Permata ${ }^{1}$, Erdina Arianti ${ }^{2, b}$, R. Kusnindar Priohutomo ${ }^{2}$, dan \\ Taufan Prasetyo ${ }^{1}$
}

\author{
${ }^{1}$ Politeknik Negeri Madura, Jl. Raya Taddan KM. 4 Taddan, Camplong, Sampang, Jawa Timur, Indonesia \\ ${ }^{2}$ Balai Teknologi Hidrodinamika, Balai Teknologi Hidrodinamika, Badan Pengkajian dan Penerapan Teknologi \\ Jl. Hidrodinamika, Kompleks ITS, Surabaya, Indonesia \\ e-mail: aariefsyarifuddin05@gmail.com, berdinarianti@gmail.com
}

Diterima : 12 Oktober 2020; Direvisi: 17 November 2020; Disetujui: 23 November 2020

\begin{abstract}
Abstrak
Pulau Madura sebagai salah satu wilayah di Indonesia dengan produksi garam yang cukup tinggi, memiliki potensi untuk bisa meningkatkan produksi garamnya, demi menunjang kebutuhan swasembada garam nasional. Salah satu upaya yang dilakukan dalam meningkatkan produksi garam di pulau Madura adalah dengan membuat tambak garam lepas pantai. Pengembangan tambak garam lepas pantai tentu menjadi tantangan tersendiri, karena memperhitungkan banyak faktor, salah satunya adalah faktor lingkungan yaitu arus, angin, dan gelombang. Penelitian ini akan membahas tentang barge atau tongkang yang dijadikan sebagai tambak garam lepas pantai. Analisis difokuskan kepada respon gerak yang dihasilkan oleh barge berupa grafik RAO (Response Amplitude Operator). Analisis untuk RAO pada penelitian menghasilkan gerakan barge yang cukup baik. Gerakan vertikal barge pada kondisi muatan penuh menghasilkan nilai terbesar sebagai berikut : heave bernilai $0,863 \mathrm{~m} / \mathrm{m}$ pada arah pembebanan $90^{\circ}$ dan frekuensi $0,2 \mathrm{rad} / \mathrm{sec}$; roll bernilai $5,674 \mathrm{deg} / \mathrm{m}$ pada arah $45^{\circ}$ dengan frekuensi $0.4 \mathrm{rad} / \mathrm{sec}$; sedangkan untuk pitch bernilai $0,917 \mathrm{deg} / \mathrm{m}$ akibat arah pembebanan $180^{\circ}$ dan frekuensi 0,2 rad/sec. Gerakan vertikal barge penting untuk diperhatikan karena memberikan pengaruh yang lebih dominan dibandingkan gerakan horizontal (surge, sway, dan yaw) terhadap stabilitas kapal dan kelaiklautan kapal (seaworthiness).
\end{abstract}

Kata kunci: garam; tambak garam; barge; RAO

\begin{abstract}
Madura Island, as one of the regions in Indonesia with quite high salt production, has the potential to increase its salt production, in order to support the national salt self-sufficiency program. One of the methods used to increase salt production on the island of Madura is by establishing an offshore salt pond. The development of offshore salt ponds certainly has many challenges, because it takes into account many factors, one of which is environmental factors, namely currents, winds and waves. This research will discuss about the barge which is used as an offshore salt pond. The analysis is focused on the response to motion generated by the barge in the form of RAO (Response Amplitude Operator) graphs. The analysis for RAO in this study resulted in a fairly
\end{abstract}


good barge movement. The vertical movement of the barge under full load produces the largest value as follows, heave is $0.863 \mathrm{~m} / \mathrm{m}$ in the load direction of $90^{\circ}$ and a frequency of $0.2 \mathrm{rad} / \mathrm{sec}$; roll has a value of $5.674 \mathrm{deg} / \mathrm{m}$ in the $45^{\circ}$ direction with a frequency of $0.4 \mathrm{rad} / \mathrm{sec}$; while the pitch is $0.917 \mathrm{deg} / \mathrm{m}$ due to the load direction of $180^{\circ}$ and a frequency of $0.2 \mathrm{rad} / \mathrm{sec}$. The vertical barge movement is important to note because it has a more dominant influence than horizontal movement (surge, sway, and yaw) on the stability of the ship and the seaworthiness of the ship.

Keywords: salt; salt pond; barge; RAO

\section{PENDAHULUAN}

Indonesia sebagai negara dengan garis pantai terpanjang keempat di dunia, yaitu 95.181 km, memiliki potensi yang luar biasa terhadap sumber daya alam kelautannya (Rusiyanto dkk., 2013). Garis pantai yang sangat panjang juga memberikan manfaat yang begitu banyak bagi masyarakat Indonesia, mulai dari nelayan yang bisa memperoleh banyak ikan, hingga potensi garam yang mampu dihasilkan oleh petani garam di Indonesia. Pemanfaatan garam nasional pada tahun 2013 untuk kebutuhan konsumsi adalah sebesar 1,4 juta ton (dimana sekitar 500 ribu ton diimpor), sedangkan untuk kebutuhan industri adalah sebesar 1,8 juta ton (Efendy dkk., 2014). Kebutuhan impor yang masih sangat tinggi telah coba ditanggulangi oleh pemerintah dengan program ekstensifikasi, intensifikasi, dan revitalisasi lahan tambak garam.

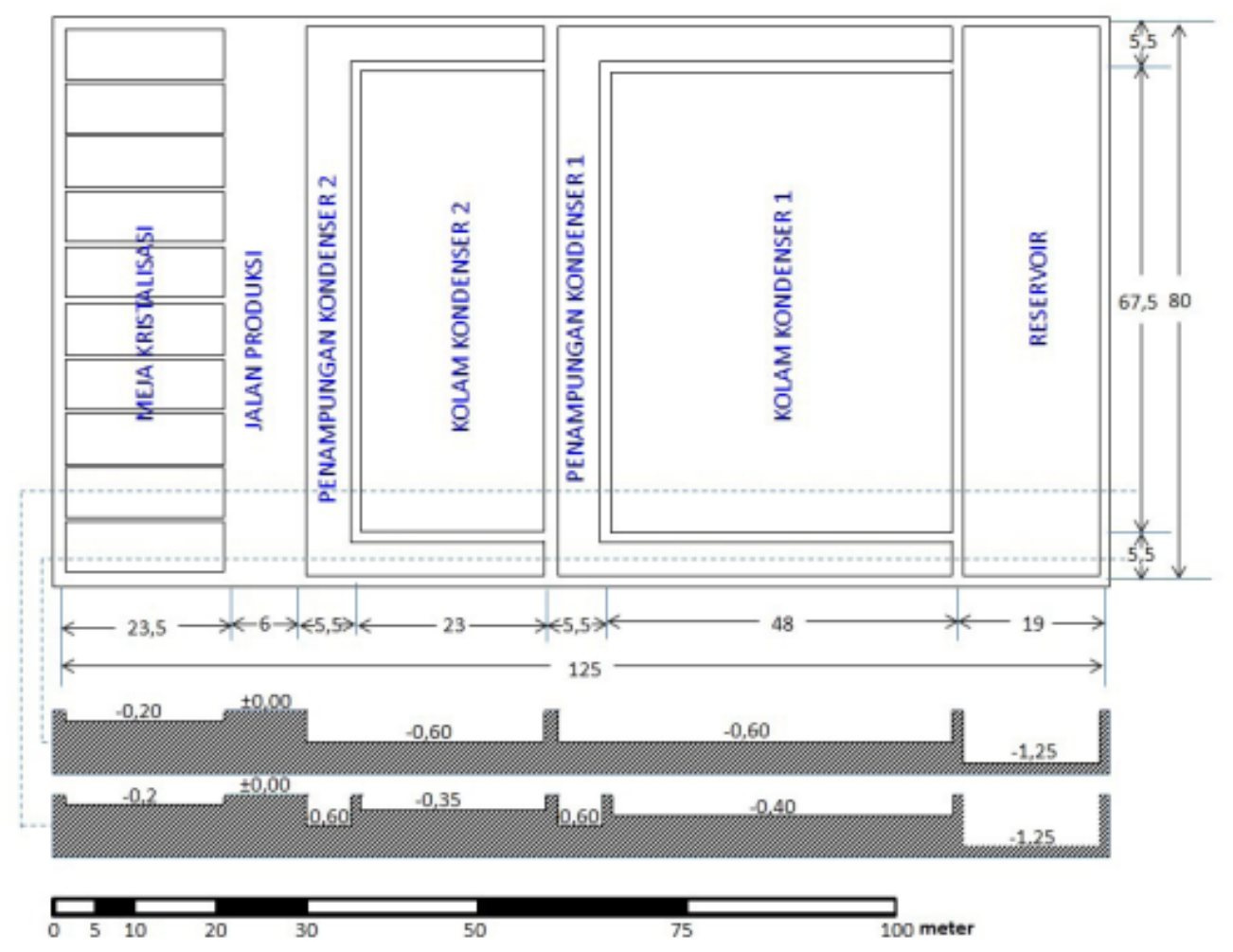

Gambar 1. Layout tambak garam semi intensif (Bramawanto, 2017)

Pulau Madura adalah salah satu wilayah di Indonesia dengan produksi garam yang cukup tinggi. Data yang ada menyatakan bahwa untuk satu kabupaten saja yaitu kabupaten Pamekasan mampu memproduksi garam sebesar 98.000 ton pada tahun
2013 (setara dengan 30\% produksi garam Madura atau $10 \%$ produksi garam nasional) (Efendy dkk., 2014). Produktivitas garam di pulau Madura tentu masih bisa dikembangkan lebih jauh, demi menunjang kebutuhan swasembada garam nasional. 
Salah satu upaya yang dilakukan dalam meningkatkan produksi garam di pulau Madura adalah dengan membuat tambak garam lepas pantai.

Pengembangan tambak garam lepas pantai tentu menjadi tantangan tersendiri, karena memperhitungkan banyak faktor, salah satunya adalah faktor lingkungan yaitu arus, angin, dan gelombang. Penelitian ini akan membahas tentang barge atau tongkang yang dijadikan sebagai tambak garam lepas pantai. Analisis difokuskan kepada respon gerak yang dihasilkan oleh barge berupa grafik RAO (Response Amplitude Operator). Layout atau tata letak tambak garam lepas pantai didasarkan kepada layout tambak garam semiintensif seperti yang tampak pada Gambar 1.

Menurut Bramawanto (2017), penggunaan lahan semiintensif seperti pada Gambar 1 mampu menghasilkan produksi garam kurang lebih 100 ton garam dalam satu kali situs produksi, jika dalam 1 (satu) periode musim kemarau adalah 100 hari atau 3,5 bulan maka lahan garam tersebut mengalami 8 kali siklus produksi, dengan rincian 35 hari siklus awal dan 10 hari x 7 kali (siklus masa pungut garam). Analisis RAO diharapkan bisa menjadi tolak ukur awal bahwa barge bisa dioperasikan secara baik dan memberikan kelayakan laut (seaworthiness) yang baik.

\section{TINJAUAN PUSTAKA}

\section{Gambaran Umum Barge atau Tongkang}

Barge adalah suatu jenis kapal dengan lambung datar atau suatu kotak besar yang mengapung. Barge biasa digunakan untuk mengangkut barang dan ditarik dengan kapal tunda (Papalangi dkk., 2015).

Karakteristik yang dimiliki oleh barge atau tongkang adalah sebagai berikut (Adietya dan Arifin, 2011):

1. Hanya membawa barang di atas geladak;

2. Tidak berawak;

3. Tanpa pendorong sendiri;

4. Tidak memiliki lubang palkah;

5. Mempunyai perbandingan antara lebar dan tinggi tidak lebih dari 3,0;
6. Mempunyai koefisien blok (Cb) 0,9 atau lebih.

\section{Gambaran Umum Tambak Garam}

Tambak garam merupakan area yang disediakan atau dibuat untuk menghasilkan garam dari air laut. Tambak garam rakyat di Indonesia pada umumnya dikelola dalam ukuran kecil. Pada kabupaten Sampang, Pamekasan, Sumenep, Indramayu, dan Cirebon rata-rata lahan tambak garam adalah 0,3 sampai 1,7 ha per orang (Bramawanto, 2017).

\section{Rencana Garis (Lines Plan)}

Lines plan adalah gambar rencana garis dari bentuk badan kapal. Tujuan dari pembuatan lines plan adalah untuk mengetahui bentuk badan kapal terutama yang terletak di bawah garis air. Gambar lines plan terbagi menjadi tiga (Jumantara dkk., 2017), yaitu :

1. Half breadth plan adalah pandangan atas dari lambung kapal yang dipotong secara horizontal memanjang dan memperlihatkan bentuk garis air (water lines);

2. Sheer plan adalah pandangan samping dari lambung kapal yang dipotong secara vertikal memanjang, memperlihatkan potongan memanjang badan kapal (buttock lines), dan bentuk sheer kapal;

3. Body plan adalah pandangan depan atau belakang dari suatu lambung kapal yang dipotong secara melintang dan memperlihatkan bentuk gading-gading kapal.

\section{Rencana Umum (General Arrangement)}

General arrangement atau rencana umum adalah gambar dua dimensi kapal dengan dua sudut pandang yaitu sudut pandang atas dan samping, tujuan dari dibuatnya general arrangement adalah untuk memberikan rancangan kapal secara umum serta kelengkapan yang berada pada kapal itu (Novita dkk., 2016).

\section{Olah Gerak Bangunan Apung}

Pada dasarnya benda yang mengapung 
mempunyai enam mode gerakan bebas yang terbagi menjadi dua kelompok, yaitu tiga mode gerakan translasi dan tiga mode gerakan rotasi. Berikut adalah keenam mode gerakan tersebut (Suwarsono dkk., 2012):

1. Mode gerak translasi
a. Surge, gerakan transversal arah sumbu x;
b. Sway, gerakan transversal arah sumbu y;
c. Heave, gerakan transversal arah sumbu z.

2. Mode gerak rotasi

a. Roll, gerakan rotasi arah sumbu x;

b. Pitch, gerakan rotasi arah sumbu y;

c. Yaw, gerakan rotasi arah sumbu z.

Representasi dari gerakan translasi dan rotasi dapat dilihat pada Gambar 2.

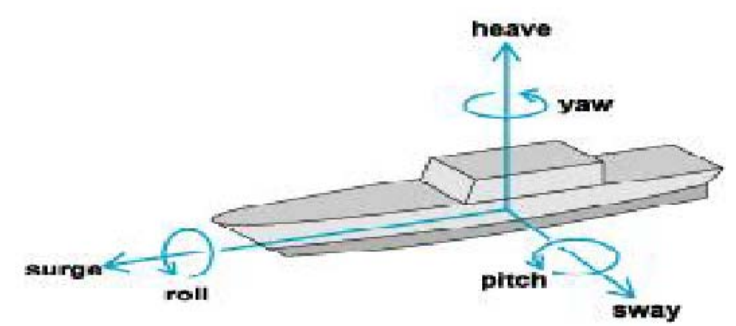

Gambar 2. Mode gerak yang dialami oleh struktur terapung (Suwarsono dkk., 2012)

\section{Response Amplitude Operator (RAO)}

Data barge digunakan untuk proses pemodelan yang selanjutnya akan digunakan untuk analisis karakteristik perilaku gerak struktur kondisi terapung bebas pada gelombang reguler. Analisis tersebut sering disebut analisis hidrodinamis di mana salah satu output-nya berupa RAO (Response Amplitude Operators). Analisis hidrodinamis diperoleh dengan menggunakan analisis domain frekuensi (Arianti, 2018).

RAO adalah fungsi respon yang terjadi akibat gelombang dalam rentang frekuensi yang mengenai struktur. Hal ini dikarenakan RAO adalah alat untuk mentransfer beban luar (gelombang) dalam bentuk respon pada suatu struktur. Respon gerakan RAO terbagi menjadi dua yaitu: (Djatmiko, 2012):

1. Respon gerakan RAO untuk gerakan translasi yaitu surge, sway, dan heave $(\mathrm{k}=1,2,3$ atau $\mathrm{x}$, $\mathrm{y}, \mathrm{z}$ ), merupakan perbandingan langsung antara amplitudo gerakannya dibanding dengan amplitudo gelombang (dalam satuan panjang). Persamaan (1) digunakan untuk menentukan RAO gerakan translasi.

$R A O=\frac{\zeta_{k 0}}{\zeta_{0}}(m / m)$

2. RAO untuk gerakan rotasi yaitu roll, pitch, dan yaw $(\mathrm{k}=4,5,6$ atau $\theta, \phi, \psi)$ adalah perbandingan antara amplitudo gerakan rotasi dengan kemiringan gelombang (hasil kali antara angka gelombang dengan amplitudo gelombang insiden). Persamaan (2) digunakan untuk menentukan RAO gerakan rotasi.

$R A O=\frac{\zeta_{k 0}}{k_{w} \zeta_{0}}=\frac{\zeta_{k 0}}{\left(\omega^{2} / g\right) \zeta_{0}}(\mathrm{rad} / \mathrm{rad})$

\section{METODE PENELITIAN}

\section{Data Barge}

Data barge yang digunakan pada penelitian ini tersaji pada Tabel 1 berikut ini:

Tabel 1. Dimensi utama barge

\begin{tabular}{lrl}
\hline LoA (Length Overall) & 310 & $\mathrm{~m}$ \\
\hline LwL (Length Waterlines) & 310 & $\mathrm{~m}$ \\
\hline Lpp (Length Perpendicular) & 310 & $\mathrm{~m}$ \\
\hline B (Lebar) & 65 & $\mathrm{~m}$ \\
\hline D (Tinggi) & 27,3 & $\mathrm{~m}$ \\
\hline T (Sarat) & 13,8 & $\mathrm{~m}$ \\
\hline Cb (Koefisien Blok) & 0,951 & \\
\hline
\end{tabular}

\section{Rencana Garis (Lines Plan)}

Desain lines plan untuk kapal barge yang digunakan pada penelitian ini dapat dilihat pada Gambar 3. Pada gambar lines plan menunjukkan barge yang dilihat dari depan atau belakang, dari atas, dan dari samping. Lines plan untuk barge tidak serumit lines plan untuk kapal pada umumnya, hal ini dikarenakan bentuk dari barge yang menyerupai balok.

\section{Rencana Umum (General Arrangement)}

General arrangement pada barge yang digunakan untuk penelitian ini menerapkan layout garam semiintensif yang tersaji pada Gambar 1 untuk diletakkan di atas barge yang berukuran 


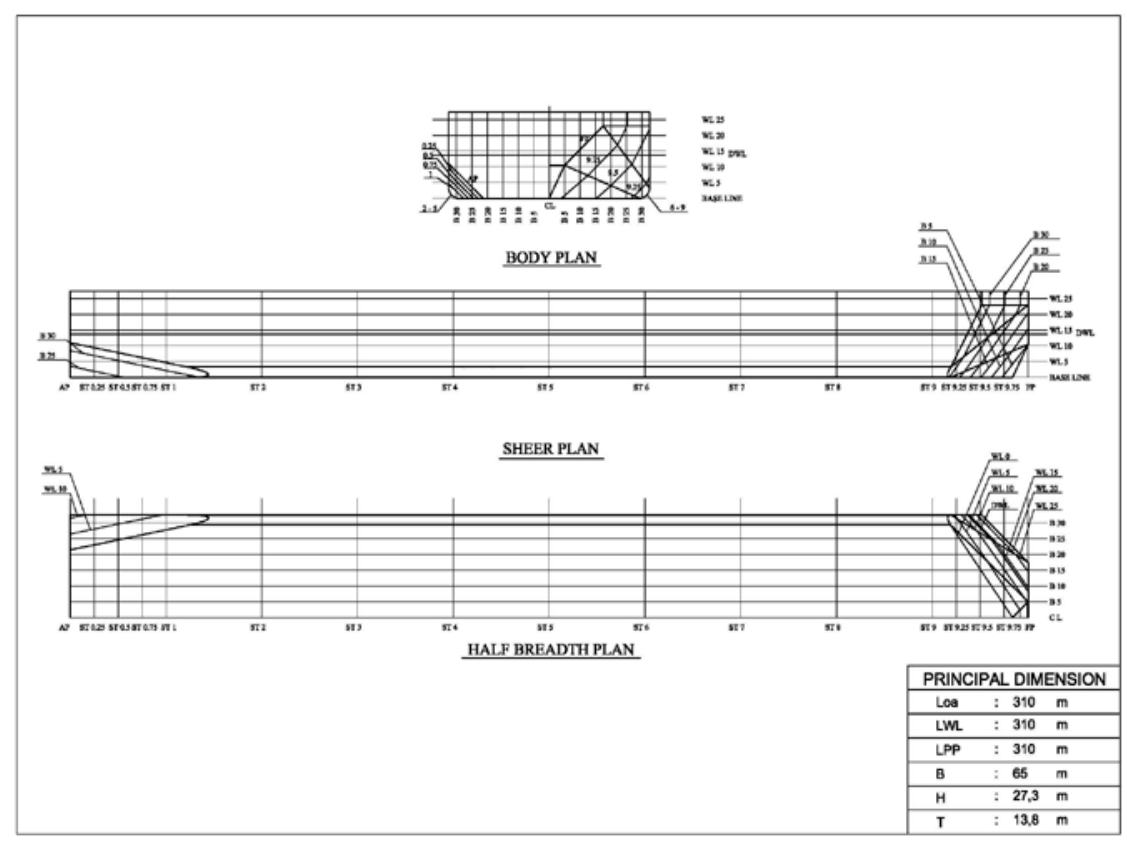

Gambar 3. Lines plan dari barge yang dianalisis

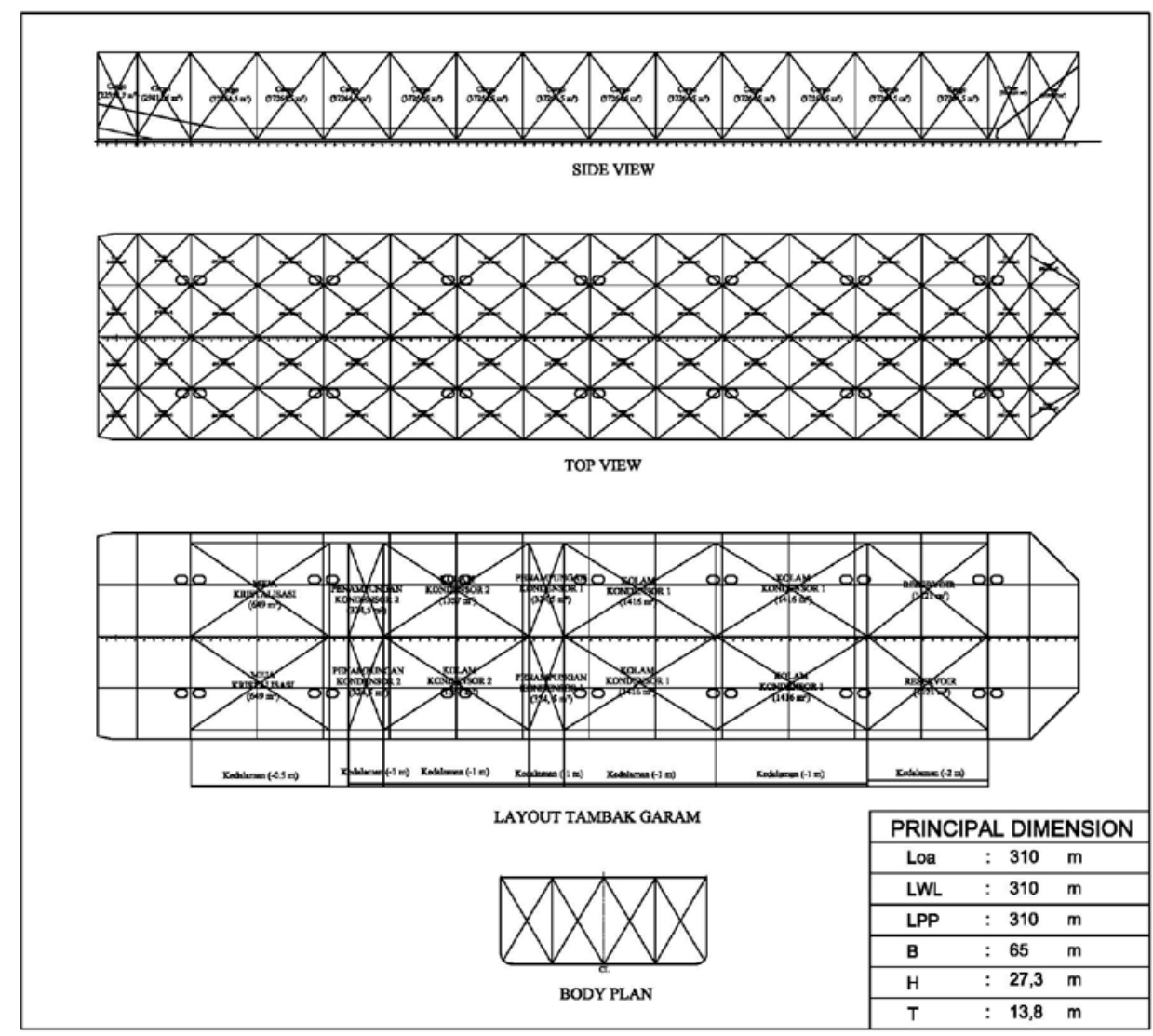

Gambar 4. General arrangement dari barge

310 m atau hampir tiga kali lipat lebih besar dari kebutuhan lahan pada Gambar 1. Sehingga diharapkan dengan menggunakan barge ini produksi garam yang dihasilkan bisa meningkat setidaknya dua kali lipat atau sekitar 200 ton untuk satu kali musim panen. Gambar 4 menunjukkan desain dari rencana umum barge yang digunakan pada penelitian ini. 

(Arief Syarifuddin, Tristiandinda Permata, Erdina Arianti, R. Kusnindar Priohutomo dan Taufan Prasetyo)

\section{Pembuatan Model}

Pembuatan model barge menggunakan bantuan perangkat lunak Maxsurf Modeler. Setelah dilakukan pemodelan di Maxsurf Modeler, model barge dikonversi ke Maxsurf Motion. Beberapa tahapan yang perlu diperhatikan ketika di Maxsurf Motion adalah sebagai berikut:

1. Meshing barge

Meshing adalah proses diskritisasi domain fluida yang kontinu menjadi domain komputasi yang diskrit sehingga persamaan-persamaan (dalam kasus ini aliran fluida) di dalamnya dapat diselesaikan dan menghasilkan solusi.

Semakin kecil proses pencacahan, maka hasil luas permukaan yang diperoleh akan semakin akurat. Namun, jika diskritisasi/pencacahan terlalu banyak, maka persamaan yang dihasilkan akan semakin banyak dan membutuhkan proses komputasi yang terlalu lama (Wiratama, 2019). Pada Maxsurf Motion proses meshing menghasilkan diskritisasi sebanyak 3000 elemen, seperti yang terlihat pada Gambar 5.

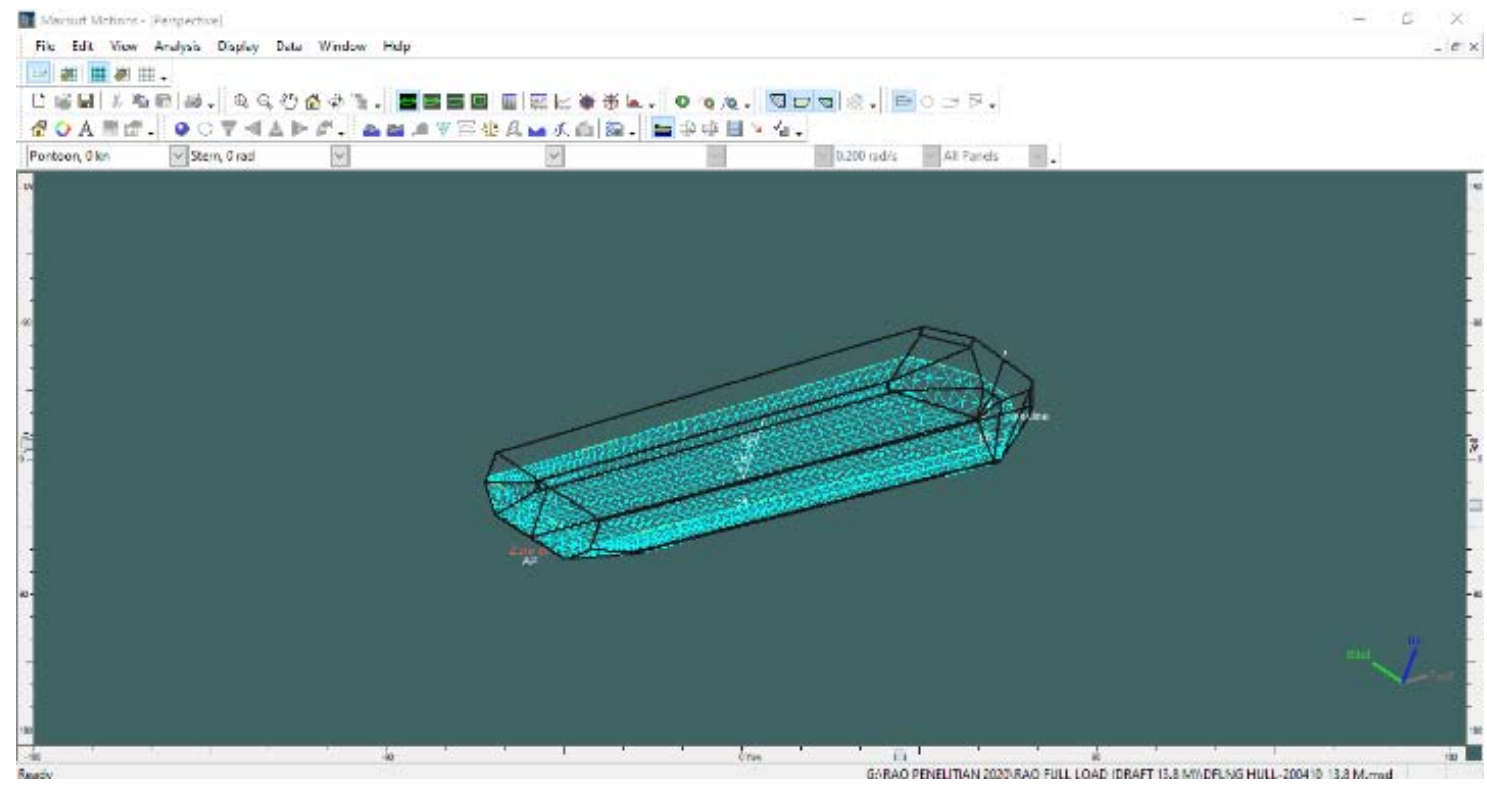

Gambar 5. Meshing barge kondisi muatan penuh

2. Arah pembebanan

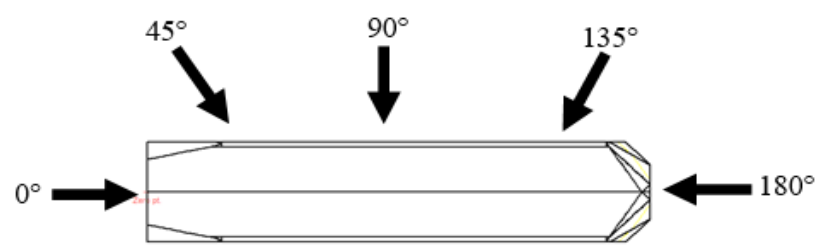

\section{Gambar 6. Arah pembebanan untuk analisis RAO}

Arah pembebanan (heading) yang mengenai barge terbagi menjadi lima sudut pembebanan yaitu $0^{\circ}$ (stern), $45^{\circ}$ (stern quartering), $90^{\circ}$ (beam), $135^{\circ}$ (bow quartering), dan $180^{\circ}$ (head). Pada Gambar 6 dapat diketahui bahwa arah $0^{\circ}$ menunjukkan bahwa beban yang mengenai barge datang dari arah belakang barge, sedangkan arah $180^{\circ}$ datang dari arah depan barge. Analisis RAO nilai kecepatan yang digunakan adalah $0 \mathrm{~m} / \mathrm{s}$ atau kondisi stasioner $(\mathrm{Fn}=0)$.

3. Mass distribution, frequency range, dan environment

Data yang diperlukan sebagai masukan pada perangkat lunak Maxsurf Motion tersaji pada Tabel 2-4.

Tabel 2. Data mass distribution

\begin{tabular}{cc}
\hline \multicolumn{2}{c}{ Mass distribution } \\
\hline Roll gyradius & $26 \mathrm{~m}(40 \%$ Boa $)$ \\
\hline Pitch gyradius & $77 \mathrm{~m}(25 \%$ Loa $)$ \\
\hline Yaw gyradius & $77 \mathrm{~m}(25 \%$ Loa $)$ \\
\hline VCG & $18,5 \mathrm{~m}$ \\
\hline
\end{tabular}


Tabel 3. Data untuk frequency range

Frequency range

\begin{tabular}{cc}
\hline Start & $0,2 \mathrm{rad} / \mathrm{s}$ \\
\hline End & $2,0 \mathrm{rad} / \mathrm{s}$ \\
\hline Number of frequencies & 91 \\
\hline
\end{tabular}

Tabel 4. Data lingkungan

\begin{tabular}{cc}
\hline \multicolumn{2}{c}{ Environment } \\
\hline Water density & 1,025 ton $/ \mathrm{m}^{3}$ \\
\hline Water depth & depth water \\
\hline
\end{tabular}

\section{HASIL DAN PEMBAHASAN}

Respon gerak barge yang dianalisis pada penelitian ini tersaji dalam bentuk RAO kondisi muatan penuh. Hal yang penting pada kondisi barge mengapung bebas atau tanpa adanya penambatan akan lebih sesuai jika mode gerakan yang dibahas terlebih dahulu adalah mode gerakan vertikal, yaitu heave, roll, dan pitch. Hal tersebut dikarenakan gerakan vertikal memiliki pengaruh yang lebih dominan dibandingkan dengan gerakan horizontal (surge, sway, dan yaw) terhadap stabilitas kapal dan kelaiklautan kapal (seaworthiness).

RAO pada kondisi muatan penuh tersaji dalam lima variasi pembebanan yaitu $0^{\circ}$ (stern), $45^{\circ}$ (stern quartering), $90^{\circ}$ (beam), $135^{\circ}$ (bow quartering), dan $180^{\circ}$ (head).

\section{RAO Gerakan Vertikal}

RAO untuk gerakan vertikal yaitu heave, roll, dan pitch tersaji pada Gambar 7-9. Gerakan heave seperti yang tampak pada Gambar 7, merupakan gerakan translasi searah sumbu tegak (vertikal) kapal atau dengan bahasa lebih sederhana gerakan heave adalah gerakan naik/turun kapal akibat gelombang. Jika diperhatikan pada Gambar 7, gerakan heave menghasilkan nilai yang tidak jauh berbeda antar arah pembebanan. Gerakan heave terbesar terjadi akibat arah pembebanan $90^{\circ}$ (beam seas) dengan nilai $0,863 \mathrm{~m} / \mathrm{m}$, serta pada frekuensi rendah yaitu 0,2 rad/sec. Pada RAO gerakan heave setelah mengalami resonansi utama di frekuensi rendah yaitu pada frekuensi $0,2 \mathrm{rad} / \mathrm{sec}$ untuk semua arah pembebanan, resonansi beberapa kali terjadi di frekuensi sedang hingga tinggi. Hal tersebut ditunjukkan dengan adanya beberapa puncak pada Gambar 7, hingga akhirnya gerakan heave berangsur menurun untuk frekuensi di atas $1 \mathrm{rad} / \mathrm{sec}$.

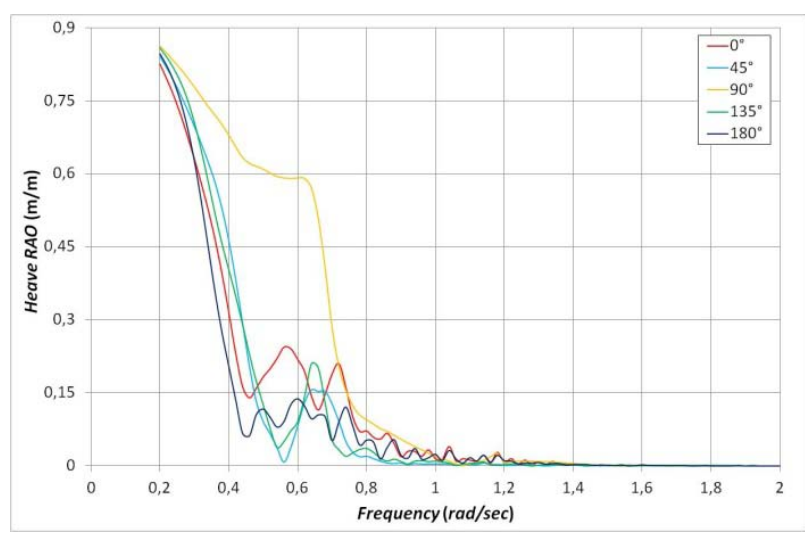

Gambar 7. RAO gerakan heave pada barge

RAO gerakan roll (oleng) adalah gerakan rotasi kapal memutari sumbu x (sumbu memanjang kapal). Gerakan ini merupakan salah satu gerakan yang penting karena berpengaruh terhadap kestabilan kapal terutama untuk gelombang yang datang tegak lurus sumbu memanjang, atau biasa disebut beam sea $\left(90^{\circ}\right)$.

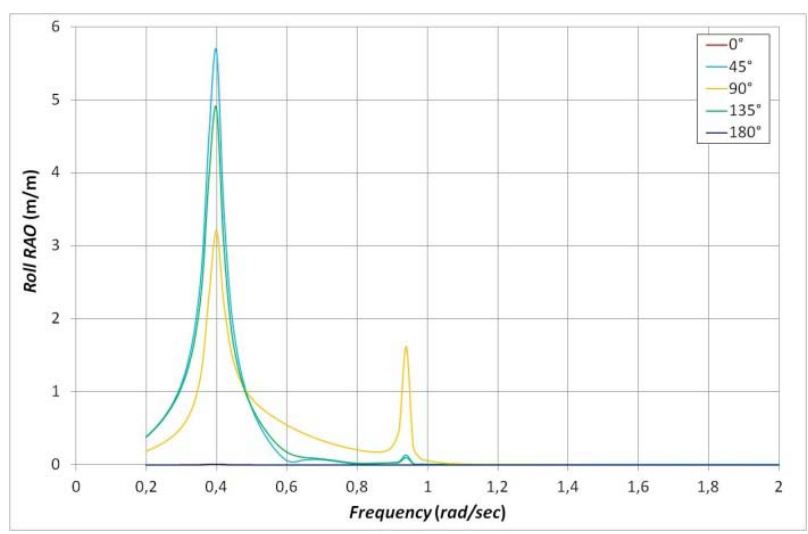

Gambar 8. RAO gerakan roll pada barge

Pada Gambar 8 dapat diketahui bahwa untuk gerakan roll paling besar dihasilkan dari arah pembebanan stern quartering $\left(45^{\circ}\right)$ yaitu $5,674 \mathrm{deg} / \mathrm{m}$ pada frekuensi rendah $(0,4 \mathrm{rad} / \mathrm{sec})$. Selain arah pembebanan $45^{\circ}$, arah pembebanan $90^{\circ}$ dan $135^{\circ}$ pada frekuensi yang sama juga mengalami gerakan roll yang cukup besar berturut-turut 
nilainya adalah 3,21 dan $4,891 \quad \mathrm{deg} / \mathrm{m} . \quad$ Arah pembebanan $0^{\circ}$ dan $180^{\circ}$ tidak mengalami gerakan roll.

Gerakan pitch (angguk) adalah gerakan rotasi kapal memutari sumbu y atau melintang badan kapal. Gerakan pitch termasuk gerakan penting dan merupakan gerakan yang sangat dipengaruhi oleh kondisi laut (sea state), kecepatan kapal, dan arah gelombang.

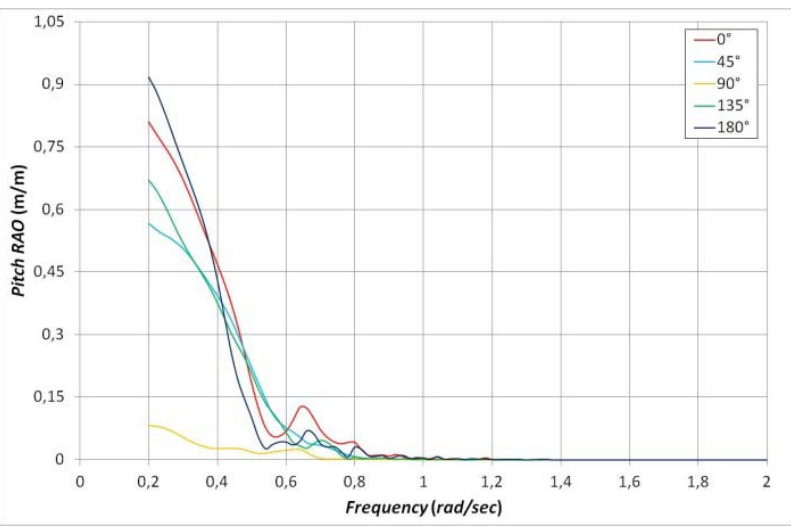

Gambar 9. RAO gerakan pitch pada barge

Gerakan pitch yang pada Gambar 9 menunjukkan bahwa nilai gerakan pitch terbesar (resonansi utama) dihasilkan oleh arah pembebanan $180^{\circ}$ pada frekuensi $0,2 \mathrm{rad} / \mathrm{sec}$ yaitu sebesar $0,917 \mathrm{deg} / \mathrm{m}$. Arah pembebanan $0^{\circ}$ pada frekuensi $0,2 \mathrm{rad} / \mathrm{sec}$ juga menghasilkan gerakan pitch yang cukup besar yaitu 0,809 deg/m. Beberapa puncak terlihat di grafik untuk frekuensi sedang, kemudian terus melandai hingga bernilai $0 \mathrm{deg} / \mathrm{m}$ pada frekuensi tinggi. Gerakan pitch akibat arah pembebanan beam seas tidak memberikan efek secara signifikan, hal ini bisa diketahui dari nilai gerakan pitch untuk arah pembebanan beam seas yang relatif kecil, gerakan pitch terbesar untuk pembebanan beam seas adalah 0,082 deg/m pada frekuensi 0,2 rad/sec. Jika diperhatikan antara grafik gerakan heave dan pitch memiliki nilai terbesar pada frekuensi $0,2 \mathrm{rad} / \mathrm{sec}$, meski nilai gerakan heave terbesar bukan dari arah $180^{\circ}$, namun nilai gerakan heave pada arah pembebanan itu juga cukup besar yaitu $0,847 \mathrm{deg} / \mathrm{m}$. Hal tersebut dikarenakan, pada kondisi stasioner efek kopel antara gerakan heave dan pitch terbesar terjadi saat gelombang berpropagasi dari buritan (Djatmiko,
2012)

\section{RAO Gerakan Horizontal}

Analisis berikutnya diberikan untuk pola gerakan horizontal dari barge yaitu surge, sway, dan yaw. RAO untuk gerakan surge, sway, dan heave tersaji pada Gambar 10-12. Gambar 10 menunjukkan bahwa untuk gerakan surge arah pembebanan stern, stern quartering, beam seas, bow quartering, dan head seas menghasilkan gerakan yang hampir sama besarnya.

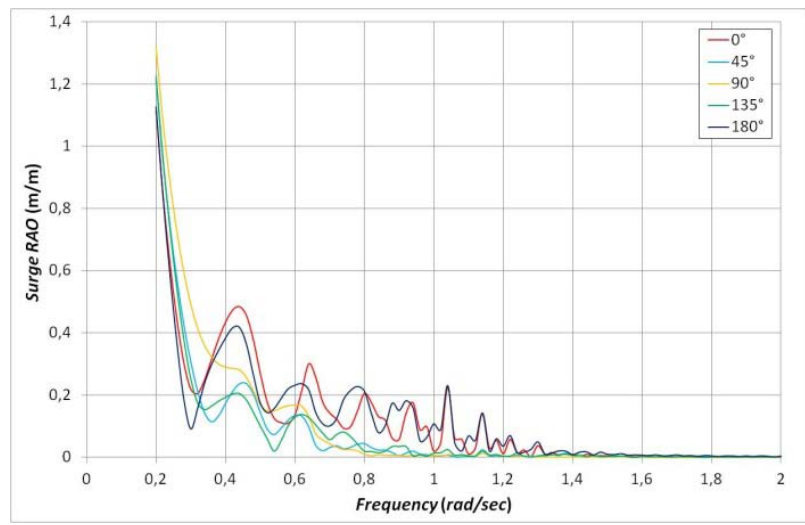

Gambar 10. RAO gerakan surge pada barge

Pada frekuensi rendah $(0,2 \mathrm{rad} / \mathrm{sec})$ arah pembebanan beam seas $\left(90^{\circ}\right)$ memiliki gerakan surge terbesar yaitu $1,317 \mathrm{~m} / \mathrm{m}$, diikuti dengan arah pembebanan $135^{\circ}$ pada frekuensi yang sama yaitu sebesar $1,225 \mathrm{~m} / \mathrm{m}$ dan $45^{\circ}$ sebesar $1,211 \mathrm{~m} / \mathrm{m}$. Gambar 10 juga memperlihatkan bahwa dari frekuensi rendah-tinggi gerakan surge masih menghasilkan beberapa puncak (mengalami beberapa resonansi) hingga akhirnya bernilai 0 .

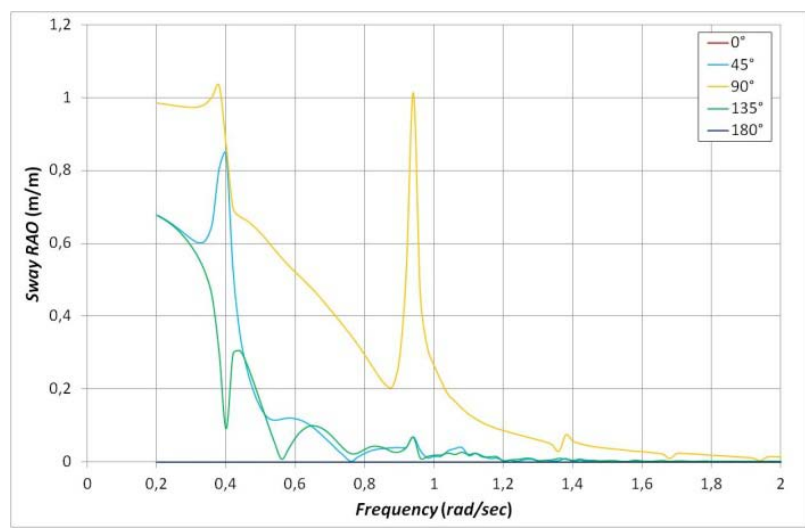

Gambar 11. RAO gerakan sway pada barge

Gerakan sway ditunjukkan oleh Gambar 11, gerakan sway terjadi paling besar akibat arah 
pembebanan beam seas $\left(90^{\circ}\right)$ pada frekuensi $0,38 \mathrm{rad} / \mathrm{sec}$ yaitu $1,032 \mathrm{~m} / \mathrm{m}$. Gerakan sway hanya terjadi di tiga arah pembebanan yaitu $45^{\circ}$ (stern quartering), $90^{\circ}$ (beam), $135^{\circ}$ (bow quartering), sedangkan untuk arah pembebanan $0^{\circ}$ dan $180^{\circ}$ gerakan sway tidak dialami oleh barge. Jika ditinjau kembali pada Gambar 11, gerakan sway juga memiliki beberapa puncak (mengalami beberapa kali resonansi).

Gerakan yaw tersaji pada Gambar 12, dari Gambar 12 dapat diketahui bahwa untuk kondisi muatan penuh, barge memiliki gerakan yaw yang jauh lebih kecil jika dibandingkan dengan kondisi lightship yaitu $1,917 \mathrm{deg} / \mathrm{m}$ pada frekuensi $0,4 \mathrm{rad} / \mathrm{sec}$ dan arah pembebanan $45^{\circ}$. Secara teoritis gerakan yaw akan terjadi sangat besar akibat arah pembebanan beam seas, diikuti dengan arah pembebanan stern quartering dan bow quartering, sedangkan untuk arah stren dan head gerakan yaw bernilai 0 atau barge tidak mengalami yaw. Pada arah pembebanan $90^{\circ}$ dan $135^{\circ}$ dengan frekuensi $0.4 \mathrm{rad} / \mathrm{sec}$ secara berturut-turut gerakan yaw yang dihasilkan adalah 1,058 dan 1,432 deg/m.

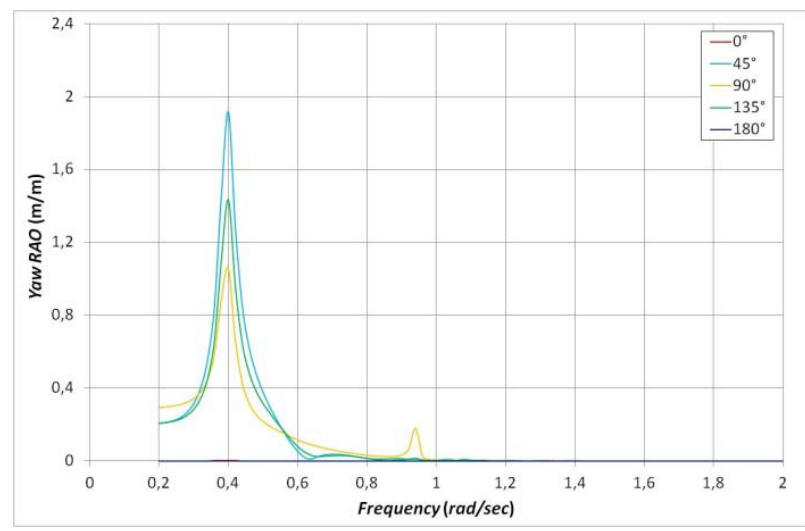

Gambar 12. RAO gerakan yaw pada barge

\section{KESIMPULAN}

Hasil yang telah diperoleh dari penelitian menunjukkan bahwa dari general arrangement barge yang telah disesuaikan dengan tambak garam semiintensif diperkirakan mampu menghasilkan 200 ton garam tiap musimnya. Analisis respon gerak untuk barge juga menunjukkan hasil yang cukup baik. RAO untuk kondisi muatan penuh terbagi menjadi RAO akibat gerakan vertikal dan horizontal.
Gerakan vertikal barge menghasilkan nilai terbesar sebagai berikut heave bernilai $0,863 \mathrm{~m} / \mathrm{m}$ pada arah pembebanan $90^{\circ}$ dan frekuensi $0,2 \mathrm{rad} / \mathrm{sec}$; roll bernilai $5,674 \mathrm{deg} / \mathrm{m}$ pada arah $45^{\circ}$ dengan frekuensi 0,4 rad/sec; sedangkan untuk pitch bernilai $0,917 \mathrm{deg} / \mathrm{m}$ akibat arah pembebanan $180^{\circ}$ dan frekuensi 0,2 rad/sec. Sedangkan untuk gerakan horizontal menghasilkan nilai terbesar sebagai berikut, surge bernilai $1,317 \mathrm{~m} / \mathrm{m}$ pada arah pembebanan $90^{\circ}$ dan frekuensi $0,2 \mathrm{rad} / \mathrm{sec}$; sway bernilai $1,032 \mathrm{~m} / \mathrm{m}$ pada arah $90^{\circ}$ dengan frekuensi $0,38 \mathrm{rad} / \mathrm{sec}$; sedangkan untuk yaw bernilai 1,917 $\mathrm{deg} / \mathrm{m}$ akibat arah pembebanan $45^{\circ}$ dan frekuensi $0,4 \mathrm{rad} / \mathrm{sec}$.

\section{UCAPAN TERIMA KASIH}

Peneliti mengucapkan terima kasih kepada Politeknik Negeri Madura yang telah memberikan pendanaan atas terlaksananya penelitian. Peneliti juga mengucapkan terima kasih kepada Balai Teknologi Hidrodinamika (BTH) yang telah bersedia memberikan data yang dibutuhkan, meminjamkan fasilitas dan software Maxsurf, serta tenaga ahlinya selama proses pengerjaan penelitian.

\section{DAFTAR PUSTAKA}

Adietya, B, A. dan Arifin, B., 2011. Analisa Kekuatan Deck pada Ponton Batubara Prawiramas Puri Prima II 1036 DWT dengan Software Berbasis Metode Elemen Hingga. Kapal, Vol. 8 (1): 1-5.

Arianti, E., 2018. Numerical Analysis of Multi Buoy Mooring Configuration Selection. Journal of Subsea and Offshore, Vol. 16 (1): $1-5$.

Bramawanto, R., 2017. Desain dan Layout Tambak Garam Semi Intensif Skala Kecil di Lahan Terbatas. Jurnal Segara, Vol. 13 (3): 159-167. Djatmiko, E. B., 2012. Perilaku dan Operabilitas Bangunan Laut di Atas Gelombang Acak. ITS Press, Surabaya.

Efendy, M., Sidik, R. F. dan Muhsoni, F. F., 2014. Pemetaan Potensi Pengembangan Lahan Tambak Garam di Pesisir Utara Kabupaten 

(Arief Syarifuddin, Tristiandinda Permata, Erdina Arianti, R. Kusnindar Priohutomo dan Taufan Prasetyo)

Pamekasan. Jurnal Kelautan, Vol. 7 (1): 1-11.

Jumantara, G. A. C., Hadi, E. S. dan Zaki, A. F., 2017. Analisa Pengaruh Sudut Masuk Kapal Perintis 750 DWT terhadap Resistance Kapal dengan Mengunakan Metode Computational Fluid Dynamic (CFD). Jurnal Teknik Perkapalan, Vol. 5 (2): 465-472.

Novita, Y., Iskandar, B. H., Imron, M. dan Nurdin, H. S., 2016. Desain Kapal Purse Seine Modifikasi di Kabupaten Bulukumba Provinsi Sulawesi Selatan. Jurnal Perikanan dan Kelautan, Vol. 6 (2): 125-136.

Papalangi, F., Mulyatno, I. P. dan Manik, P., 2015. Studi Perancangan Tongkang Pengangkut Limbah Batubara di PLTU Tanjung Jati B Jepara. Jurnal Teknik Perkapalan, Vol. 3 (2): 222-229.
Rusiyanto, Soesilowati, E. dan Jumaeri, 2013. Penguatan Industri Garam Nasional Melalui Perbaikan Teknologi Budidaya dan Diversifikasi Produk. Jurnal Sains dan Teknologi, Vol. 11 (2): 129-142.

Suwarsono, A. V., Rochani, I. dan Wardhana, W., 2012. Evaluasi Unjuk Kerja Crane Barge KGM-23 pada Saat Operasi Pengangkatan dan Pemasangan Boom Burner di Lokasi Peciko Field Platform MWP-B Total E \& P Indonesia. Jurnal Teknik ITS, Vol. 1 (1): 118-123.

Wiratama, C., 2019. Dasar-Dasar Meshing pada Computational Fluid Dyanamics (CFD). Retrieved from https://aeroengineering.co.id/2019/04/dasar-da sar-meshing-pada-computational-fluid-dynami cs-cfd/. 